\title{
The Effect of Family Interaction and Decision-Making Toward Marital Quality of Family with Migrant Husband
}

\author{
Tin Herawati* \\ Department of Family and Consumer Sciences, \\ Faculty of Human Ecology, \\ Bogor Agricultural University \\ Inne Nurajizah \\ Department of Family and Consumer Sciences, \\ Faculty of Human Ecology, \\ Bogor Agricultural University \\ *Corresponding author: tinherawati@ipb.ac.id
}

\begin{abstract}
Lagging economic conditions, especially in rural areas cause residents leave their hometown or become a migrant to get a job in order to meet the family needs. This study aimed to analyze the influence of family characteristics, family interaction, and decisionmaking on marital quality in families with migrant husband. The design of this study was cross sectional study involving wives, who had migrant husbands and teenage children (age 12-18), as respondents. The study was conducted in Banyuresmi Village, Garut Regency, West Java, Indonesia which were selected purposively. Data were collected through interview using questionnaire. The results showed that family income and conjugal interaction were the factors that allowed an increase in marital quality. On the other hand, decision-making did not have a significant effect on marital quality of the family with migrant husband.
\end{abstract}

Keywords: decision-making, family interaction, marital quality, migrant husband 


\section{INTRODUCTION}

The number of poor people in West Java is quite high, reaching 4.297.038 people with the percentage of poor people in the villages which is higher than that in the city (Statistics Indonesia, 2013). Population growth that does not go along with the growth of job opportunities makes it difficult to get a job. It leads most people go out of the village to find permanent or temporary jobs in the town. These events will certainly affect the interaction in the family. The impact of migration toward social conditions is the decreased in interaction, affection, guidance, encouragement and, protection of the father (Heru, et al., 2011). Sunarti (2013) mentions that a good interaction is indispensable in the family because it will bring happiness, harmony, and the perpetuation of marital satisfaction.

Good interaction is very important because it may influence family life; otherwise, bad interaction will adversely influence family life. The results study of Yigibalom (2013) showed that poor interaction between family members in many aspects of life will lead to family conflict or disharmony. According to Iskandar (2007), loosening of interaction between family members can lead to misunderstanding so that decision-making at the family level becomes less precise. Mackey \& O'Brien (1995) revealed that decision-making undertaken together, especially in children and parenting problems will increase the level of marital satisfaction. Chmielewska (2012) has mentioned that decision-making should be made together because the more a person control his partner, the lower the quality of the marriage.

Based on the data from the Ministry of Religion (2013) the divorce rate in Indonesia increased to 14.6 percent, or 324527 couples. The divorce rate in Garut district continues to increase from year to year. According to the Ministry of Religious Affairs Garut (2013) in Garut divorce rate is as much as 1175 then increased in 2014 with the 1747 figures. The causes of divorce vary between the couple to each other. Based on data from the Religious Court Garut (2014) factors causing most dominating divorce is no responsibility, no harmony and economic issues. The cause of divorced vary between one couple to another. According to Stanley \& Markman (2001), some of the factors that lead to divorce, namely the lack of interaction between spouses, low commitment, economic problems, spouse rarely comes home, and the absence of emotional intimacy with children and couples.

In addition to impacting the relationship of a couple, farewell father also had an impact on the interaction between children and parents. According Gunarsa (2004) social interaction that occurs in the family does not occur by itself, but because there is a specific purpose to be achieved between father, mother, and child. There is a need to be achieved or the needs of different causes them interrelated and interact with each other. Parent-child interaction is important, because it can strengthen the relationship between parents with children and can provide a sense of security and help the development of children's motivation to learn. Naim (1979) suggested that the departure of the head of the household to make a living away from home are (wander) makes less than the creation of a close relationship between father and child, his father was overseas for a long time or if the home only for a short time 
The important role of the husband in the household activities would help to save the wife of excess role in the family so that my wife feel appreciated and the family atmosphere will be better (Puspitawati, 2008). There are differences in the perceived level of satisfaction between men and women in financial management activities. Decision-making is done by the wife of a dominant in the financial management activities will provide satisfaction for his wife, but the husband was considered normal thing. According to Mickey and O'Brien in Haseley (2006) decision together, especially in children and parenting problems will increase the level of marital satisfaction. When taking decisions, this should be done together because the more a person to control their partner, the lower the quality of the marriage (Chmielewska, 2012). According to Iskandar (2007) Loosening of interaction between members can lead to misunderstanding so that decisionmaking at the family level becomes less precise. Results Yigibalom study (2013) showed that the interaction between members of families with poor family conflict or disharmony. Based on that, this study was conducted to analyze the influence of family interaction and family decision making on the quality of marriage in families with an immigrant husband.

Family interaction is determined by the quality of communication and adhesion that occurs between members of the family (Puspitawati, 2012). The interaction in families with a husband would wander distracted because her husband left the house in a long time to work. Less interaction will have an impact on decision making improper. If the interaction within the family is not good, it will badly degrade the quality of marriage and are at risk for the occurrence of the problems one divorce. Nurcahyanti (2010) mentioned that the bad interaction between husband and wife will cause problems within the family, especially to the quality of marriage. The existence of an interference and a failure in communication and affection would likely lead to decrease happiness and marital satisfaction. Under these conditions, the study aimed to: (1) identify the characteristics of family with migrant husband; (2) identify family interaction, decision-making and the quality of marriage in family with migrant husband; and (3) analyze the influence of family characteristics, family interaction, and decision-making on the quality of marriage in family with migrant husband.

\section{RESEARCH METHOD}

This research used cross sectional design study. The research was conducted in Banyuresmi Village, Garut Regency, West Java, Indonesia. This location was chosen due to the fact that it was a village of the highest number of migrant husbands in Garut area. The population of this research was a family with husband migrants residing in Banyuresmi Village. The sample criteria were a family who had a migrant husband, had teenage children aged 12-18, and willing to be a participant. As many as 60 wives were chosen purposively as the respondent. 
The type of data used were primary data. The primary data came from an interview through a questionnaire given to respondents. Questionnaire characteristics of the family (husband and wife) included age, length of education, occupation, family size, and income which were all given in open questions. The questionnaire of family interaction was modified from Setioningsih (2010) with 60 items of questions and the reliability value of 0.773 . The questions were rated on a 3 -point scale $(1=$ never, $2=$ sometimes, $3=$ often $)$. The questionnaire of decision making was adapted and modified from Puspitawati (2012) with 28 items of questions and the reliability value of 0.743 . This questionnaire used a 5-point Likert scale $(1=$ wife only, $2=$ dominant wife, $3=$ together, $4=$ dominant husband, 5 = husband only). Meanwhile, marital quality was measured using a modified questionnaire from Conger, et al. (1990) developed by Sunarti et al. (2005) with 42 items and the reliability value of 0.868 . The scale used in this questionnaire was a 3 -point scale $(1=$ frequently, $2=$ sometimes, $3=$ never $)$.

Obtained score from each variable was then transformed into index score. This aimed to get the minimum score of 0 and maximum score of 100 so that each variable could have the equal unit (Puspitawati \& Herawati, 2013). The index value would be projected into three different categories: low (00.00-33.33), moderate (33.34-66.67), and high (66.68-100.00). The index formula is as follows:

$$
\text { Index }=\frac{\text { obtained score }- \text { minimum score }}{\text { maximum score }- \text { minimum score }}
$$

Data were analyzed using descriptive analysis covering standard deviation, minimum value, maximum value, and average to interpret the variables. Besides, inferential analysis was also used for advanced analysis that was multiple linear regression test. This test aimed to analyze the influence of the independent variables (family characteristics, family interaction, and decision-making) on the dependent variable (marital quality).

\section{RESULT}

\section{Family Characteristics}

The average age of wives was 40 years old and the husbands was 44 years old. The latest education level of husbands and wives was largely primary school. Three quarters of husbands worked as labors (76.7\%) and the rest worked as entrepreneurs $(23.3 \%)$. More than three-quarters of wives $(80 \%)$ chose to be a housewife while the rest was traders (15\%) and other occupations (5\%). Most of the families in this study consisted of three to nine people with an average family size of five people. Meanwhile, husbands worked out of town for at least 2 weeks and a maximum of 24 weeks. Family income per capita per month ranged between Rp142.857 and Rp1.700.000 with the average of Rp547.946. Therefore, more than half of the families were not in poor category $(81.7 \%)$. However, it was found that nearly a fifth remained as poor $(18.3 \%)$. 


\section{Mother-Child Interaction}

Based on data on Table 1, more than three-quarters of respondents $(93.3 \%)$ in this study have interaction at high level while the rest is at moderate level $(6.7 \%)$. It indicates that nearly all mother and children communicate very well and have very good attachment. According to Yigibalom (2013), good interaction is required in family life in order to create the atmosphere of a harmonious life.

Table 1 Distribution of respondents based on mother-child interaction category

\begin{tabular}{lcccccc}
\hline Category & \multicolumn{2}{c}{ Communication } & \multicolumn{2}{c}{ Attachment } & \multicolumn{2}{c}{ Total } \\
\cline { 2 - 7 } & $\mathrm{n}$ & $\%$ & $\mathrm{n}$ & $\%$ & $\mathrm{n}$ & $\%$ \\
\hline Low (00.00-33.33) & 0 & 0.00 & 0 & 0.00 & 0 & 0.00 \\
Moderate (33.34-66.67) & 6 & 10.00 & 10 & 16.70 & 4 & 6.70 \\
High (66.68-100.00) & 54 & 90.00 & 50 & 83.30 & 56 & 93.30 \\
\hline Total & 60 & 100.00 & 60 & 100.00 & 60 & 100.00 \\
\hline
\end{tabular}

\section{Father-Child Interaction}

Table 2 shows that communication and attachment between father and child are mostly at moderate level $(66.7 \%)$. This indicates that even though father is not always at home, he still tries to establish and maintain a good interaction with his child. However, unlike mother-child interaction, there was one respondent perceiving father-child interaction at low level.

Table 2 Distribution of respondents based on father-child interaction category

\begin{tabular}{lcccccc}
\hline Category & \multicolumn{2}{c}{ Communication } & \multicolumn{2}{c}{ Attachment } & \multicolumn{2}{c}{ Total } \\
\cline { 2 - 7 } & $\mathrm{n}$ & $\%$ & $\mathrm{n}$ & $\%$ & $\mathrm{n}$ & $\%$ \\
\hline Low (00.00-33.33) & 1 & 1.70 & 2 & 3.30 & 1 & 1.70 \\
Moderate (33.34-66.67) & 36 & 60.00 & 47 & 78.30 & 40 & 66.70 \\
High (66.68-100.00) & 23 & 38.20 & 11 & 18.30 & 19 & 31.70 \\
\hline Total & 60 & 100.00 & 60 & 100.00 & 60 & 100.00 \\
\hline
\end{tabular}

\section{Conjugal Interaction}

Based on Table 3, it can be seen that more than half of respondents $(88.3 \%)$ communicate and have attachment at high level. It indicates that the interaction established between husband and wife in this study is very good although they live apart and spend less time physically compared to non-migrant couples.

Table 3 Distribution of respondents based on conjugal interaction category

\begin{tabular}{lcccccc}
\hline Category & \multicolumn{2}{c}{ Communication } & \multicolumn{2}{c}{ Attachment } & \multicolumn{2}{c}{ Total } \\
\cline { 2 - 7 } & $\mathrm{n}$ & $\%$ & $\mathrm{n}$ & $\%$ & $\mathrm{n}$ & $\%$ \\
\hline Low (00.00-33.33) & 0 & 0.00 & 0 & 0.00 & 0 & 0.00 \\
Moderate (33.34-66.67) & 21 & 35.00 & 12 & 20.00 & 7 & 11.70 \\
High (66.68-100.00) & 39 & 65.00 & 48 & 80.00 & 53 & 88.30 \\
\hline Total & 60 & 100.00 & 60 & 100.00 & 60 & 100.00 \\
\hline
\end{tabular}

\section{Decision-Making}

The results showed that the educational decision making is done jointly by both husband and wife (61.7\%). This indicates that the problem of education is a shared responsibility between husband and wife. Despite separated long distances, 
husband and wife can still communicate about their children's education. Unlike decision-making regarding education, other decision-making are carried out only by wife, namely financial decision-making $(83.3 \%)$ and food $(90 \%)$, health $(56.6 \%)$ and the ownership of assets (55\%). Meanwhile, decision-making of other subsistence strategies are dominantly done by wife (58.3\%).

\section{Marital Quality}

Table 4 shows that most of respondents (73.3\%) reveal marital happiness and marital satisfaction at high level. According to Tati (2004), marital quality is affected by factors such as affection between husband and wife, mutual support, fulfilling physical and psychological needs, managing finance well, and avoiding different opinions. Puspitawati (2012) suggested that a happy marriage is a marriage based on love; it can make people feel the pleasure of what they achieved, but do not ignore what has become the basic human needs in order to meet their satisfaction.

Table 4 Distribution of respondents based on marital quality category

\begin{tabular}{lcccccc}
\hline Category & \multicolumn{2}{c}{ Marital happiness } & \multicolumn{2}{c}{ Marital satisfaction } & \multicolumn{2}{c}{ Total } \\
\cline { 2 - 6 } & $\mathrm{n}$ & $\%$ & $\mathrm{n}$ & $\%$ & $\mathrm{n}$ & $\%$ \\
\hline Low (00.00-33.33) & 0 & 0.00 & 1 & 1.70 & 1 & 1.70 \\
Moderate (33.34-66.67) & 15 & 25.00 & 16 & 26.70 & 15 & 25.00 \\
High (66.68-100.00) & 45 & 75.00 & 43 & 71.60 & 44 & 73.30 \\
\hline Total & 60 & 100.00 & 60 & 100.00 & 60 & 100.00 \\
\hline
\end{tabular}

\section{Factors that Influence Marital Quality}

As shown in Table 5, the number of Adjusted R Square of 0.284 indicated that the multiple linear regression model explains 28.4 percent the influence of the independent variables on marital quality, and the remaining 71.6 percent is influenced by other variables excluded in this study, such as the support of friends and neighbors around the residence (Kammeyer, 1987).

Table 5 Multiple regression analysis of family characteristics, family interaction, and decision making on the marital quality

\begin{tabular}{|c|c|c|c|c|}
\hline \multirow[t]{2}{*}{ Variable } & \multicolumn{3}{|c|}{ Coefficient } & \multirow{2}{*}{ Sig. } \\
\hline & $\mathrm{B}$ & Std. Error & $\beta$ & \\
\hline Constant & 24.683 & 19.007 & & 0.200 \\
\hline Age of husband (year) & 0.365 & 0.178 & 0.243 & 0.046 \\
\hline Husband's length of education (year) & -0.084 & 0.700 & -0.015 & 0.905 \\
\hline Wife's length of education (year) & 0.083 & 0.728 & 0.015 & 0.910 \\
\hline Family income (IDR) & $1.890 \mathrm{E}-6$ & 0.000 & 0.266 & $0.038 *$ \\
\hline Length of work (week) & 0.201 & 0.376 & 0.067 & 0.595 \\
\hline Number of family member (person) & 1.028 & 0.964 & 0.126 & 0.292 \\
\hline Mother-child interaction (index score) & -0.150 & 0.332 & -0.063 & 0.653 \\
\hline Father-child interaction (index score) & 0.027 & 0.269 & 0.013 & 0.921 \\
\hline Conjugal interaction (index score) & 1.220 & 0.306 & 0.576 & $0.000 * *$ \\
\hline Decision making (index score) & -0.049 & 0.144 & -0.044 & 0.735 \\
\hline Uji F & \multicolumn{4}{|c|}{3.341} \\
\hline Sig & \multicolumn{4}{|c|}{$0.002 * *$} \\
\hline R Square & \multicolumn{4}{|c|}{0.405} \\
\hline Adjusted R Square & \multicolumn{4}{|c|}{0.284} \\
\hline
\end{tabular}


The results also showed that family income significantly and positively influenced marital quality. It indicates that the increasing of family income by $\mathrm{Rp} 1$ will increase the marital quality as well $(\mathrm{B}=1.890 \mathrm{E}-6 ; \beta=0.266 ; \mathrm{p}<0.05)$. Conjugal interaction is another factor significantly and positively influencing marital quality. Marital quality will increase as the increasing of the conjugal interaction $(\mathrm{B}=1.220 ; \beta=0.576 ; \mathrm{p}<0.01)$. In contrast, family decision making had no significant effect on marital quality.

\section{DISCUSSION}

Migration has an impact on family members who are not taken along. One of the impacts is the interactions within the family. Nearly the entire respondents have a mother-child interaction in the high category. The highest achievement in the aspects of communication is that mothers give advice to children, while the lowest one is children listen to the advice given by the mother. The highest achievement in the aspects of maternal attachment is that mothers help children in solving problems. Conversely, the lowest achievement is mothers know friends of their children. This is in line with the study of Perez-Brena, et al. (2012) which stated that the mother was involved in solving children's problems more than fathers.

More than half of father-son interaction in migrant families was in medium category. According to Naim (1979) the departure of the head of the household to make a living away from home (migrated) is resulting in less creation of an intimate relationship between the father and son. Children will not familiar with his father because he is overseas for a long time or stays at home only for a short time. The highest achievement in the aspects of communication is listening to the advice given by fathers, while the lowest achievement is fathers take the time to talk about something personal about their children. The highest achievement in the aspects of attachment is fathers willing to listen and pay attention if children get in trouble, while the lowest one is fathers know friends of their children.

Most of conjugal interactions in this study are in the high category. Even though husbands are migrating, they have a fixed schedule for the return and will spend quite a lot of time at home. The better the interaction between husband and wife, the better quality of marriage (Khotibatunnisa, 2014). The highest achievement in the communication aspects, namely mutual respect. Communication is one of the factors that influence marital satisfaction. Rachmawati \& Mastuti (2013) stated that good communication and sufficient leisure time activities are of aspects that can determine marital satisfaction. The highest achievement in the aspects of attachment is that husbands entrust the financial management to their wife. This shows that despite migrated, husbands still maintain the trust to the wives in managing family income.

Financial and food decision making are mostly done by the wife alone. This is consistent with the study of Morton, et al., (1999) which stated that women were more dominant in financial decision making in the family. Education and health decision-making is largely done together. It is in accordance with the study of Perez-Brena, et al. (2012) which mentioned that decisions regarding the needs of the school and child's appearance were done collectively. Cetinkaya \& 
Gencdogan (2014) mentioned that when a husband and wife had a balanced position in food decision making, they will have higher marital satisfaction. Decision-making of assets ownership including the purchase of clothing and home furnishings are largely decided by wives, while for the purchase of electronic equipment and home improvement is largely decided by the husband. Belch \& Willis (2001) also mentioned that husbands participate in decision-making for televisions, cars and insurance, while wives are more to decide in buying household appliances and food.

Decision-making in the field of other subsistence strategy was done by wives and nothing was done jointly. Decision-making done by wives included finding additional work, having the child help with the work, as well as determining to take saving and make savings. On the other hand, decision-making done together by husbands and wives included selling/exchanging of goods, specifying where to do saving, sell assets, and debt. This is in accordance with the study of Puspa (2007) which stated that decisions in other subsistence strategies was done together. According Lamana \& Riedmann (2009), togetherness between the spouses that included decision-making, domestic work, finances, and sense of belonging will increase marital satisfaction.

The results showed that the majority of families in this study had highly marital quality. Based on the highest achievement in aspects of intimate relationship, more than three quarters of wives said that they never felt forced to do sexual intercourse when her husband returned home. According to Duvall \& Miller (1985), if the couples can enjoy their sexual relations, the marriage quality will increase. Based on the highest achievement in the aspects of love and of intimate relationships, nearly all wives were satisfied with couples who love to date. Marital satisfaction was based on love or expression of love by showing affection from time to time (Lavner, et al., 2014).

The results showed that the level of income will affect the marital quality, indicating that the higher the family income, the higher the marital quality. Duval \& Miller (1985) stated that the openness in viable and stable of economic life is the characteristic of marital happiness, and will support the satisfaction of marriage. Decision-making had no significant effect on marital quality. This is due to the fact that the decision-making in families with migrant husbands was almost entirely done by wives only, thus it did not affect the quality of the marriage. Marital interaction affects the quality of marriage. According to Zastrow \& Asham (1987), factors that existed during the marriage which affected marital happiness included excellent communication skills, an equal relationship, love, mutual respect, a relationship full of intimacy, compatibility in sexual life, as well as ability to give and take.

\section{CONCLUSIONS AND RECOMMENDATION}

\section{Conclusions}

Mother-child interaction goes well, but the father-child interactions are still in the intermediate category. This occurs because fathers have less time than mothers, so this causes lack of father-son interaction. Meanwhile, almost all the 
decisions in the family are mostly done and is dominated by the wife, the husband had taken part in the election to give an opinion with regard to the education of children. Respondents in this study have the quality of a good marriage. The factors affect the quality of the marital family income and spousal interaction. Families with higher incomes and an interaction of both husband and wife have higher marital quality as well.

\section{Recommendation}

Based on the results obtained from this study, the advice that can be given is that the government, agencies or universities are expected to do counseling about the importance of keeping the interaction within the family, both between couples and parents with children and other family members. Families are expected to increase the interaction, especially for fathers so that when the family was at home, doing activities together such as eating together or a holiday together and when the family is outside the city while maintaining communication with optimizing the communication media. In addition, further research is expected to analyze the factors that affect the quality of marriage based on the perception of the husband.

\section{Reference}

Belch, M. A., \& Willis, L. A. (2002). Family decision at the turn of the century: Has the changing structure of households impacted the family decisionmaking process?. Journal of Consumer Behaviour, 2(2), 112-124. doi: 10.1002/cb.94.

Çetinkaya, S. K., \& Gençdoğan, B. (2014). The relationship between marital quality, attitudes towards gender roles and life satisfaction among the married individuals. Psychology, Society, and Education, 6(2), 94-112. Retrieved from http://www.psye.org/articulos/Kodan.pdf.

Chmielewska, M. (2012). Marital quality in the context of interpersonal dependency. Journal Economics \& Sociology, 5(2), 58-74. Retrieved from http://www.economics-sociology.eu/files/09_Chmielewska_2_1.pdf.

Duval, E. M., \& Miller, B. C. (1985). Marriage and Family Development. New York, NY: Harper \& Row Publisher Inc.

Heru, L., Kasnawi, M. T., \& Pandu, M. E. (2011). The pattern of social economic relationship in migrant circular families (A case study in five migrant families in Gaya Baru Village, Lapandewa District, Buton Regency. E-Journal of Hasanuddin University Graduate Program, Retrieved from http://pasca.unhas.ac.id/jurnal/files/83e3829ce9ece1d270eaa589a62c25c1.pdf.

Hurlock, E. B. (2009). Developmental Psychology: A Life-Span Approach. (Istiwidayanti \& Doedjarwo, Trans.). Jakarta, Indonesia: Erlangga.

Iskandar, A. (2007). Analysis of family resource management practices and its impact on family welfare in the regency and the city of Bogor. (Unpublished master's thesis). Bogor Agricultural University, Bogor.

Kammeyer, K. C. W. (1987). Marriage and Family: A Foundation for Personal Decisions. Allyn Bacon Inc. 
Khotibatunnisa, S. (2014). Interaction with the quality of the marriage of husband and wife in a polygamous family (Undergraduate thesis). Retrieved from http://repository.ipb.ac.id/handle/123456789/69944.

Lamana, M. A., \& Riedmann, A. (2009). Marriages, Families, and Relationships: Making Choices in a Diverse Society. US: Thompson Learning.

Lavner, J. A., Karney, B. R., \& Bradbury, T. N. (2014). Relationship problems over the early years of marriage: Stability or change?. Journal of Family Psychology, 28(6), 979-985. doi: 10.1037/a0037752.

Mackey, R. A., \& O'Brien, B. A. (1995). Lasting Marriages: Men and Women Growing Together. Westport, CT: Praeger Publishers.

Morton, A., Lieberman, \& Lawrence, F. (1999). The effects of family conflict resolution and decision making on the provision of help for an elder with alzheimer's disease. Journal Gerontological Society of America, 39(2), 159166.

Naim, M. (1979). Migration Migration Patterns Minangkabau. Yogyakarta, Indonesia: Gadjah Mada University Press.

Nurcahyanti, F. W. (2010). Domestic Conflict Management. Yogyakarta, Indonesia: PT Bintang Abadi Library.

Perez-Brena, N. J., Updegraff, K. A., \& Umaña-Taylor, A. J. (2012). Father- and mother-adolescent decision-making in Mexican-origin families. Journal Youth Adolescence, 41(4), 460-473. doi: 10.1007/s10964-011-9660-8.

Puspa, A. R. (2007). Study on resilience of farm families: Wife's decision-making and its relationship with family welfare. (Unpublished undergraduate thesis). Bogor Agricultural University, Bogor.

Puspitawati, H. (2012). Gender and family: concept and reality in Indonesia . Bogor, Indonesia: IPB Press.

Puspitawati, H., \& Herawati, T. (2013). Family research method. Bogor, Indonesia: IPB Press.

Rachmawati, D., \& Mastuti, E. (2013). Differences in levels of marital satisfaction in terms of levels of marital adjustment on 1 wife's Brigif Navy marines who undergo long distance marriage. Journal of Psychology and Development, 2 (2), 73-80.

Republika. (2014, November 14). The divorce rate in Indonesia is increasing every year, this data [The divorce rate in Indonesia is increasing every year, this is the data]. Retrieved from http://www.republika.co.id/ berita/nasional/umum/14/11/14/nf0ij7-tingkat-perceraian-indonesiameningkat-setiap-tahun-ini-datanya.

Setioningsih, S. S. (2010). Analysis of parental function and family's interaction to marrital quality and child's conditions at family of migran woman workers. (Undergraduate thesis). Retrieved from http://repository.ipb.ac.id/ bitstream/handle/123456789/27312/I10sss_abstract.pdf?sequence=1\&isAllow ed $=y$.

Stanley, S. M., \& Markman, H. J. (2001). What Factors are Associated with Divorce and/or Marital Unhappiness?. USA: Prep Inc.

Statistics Indonesia. (2013). Percentage of Total Population Poor Based on the Towns and Villages in West Java in 2012-2014]. Jakarta, Indonesia: Author.

Sunarti, E. (2013). Family resilience. Bogor, Indonesia: IPB Press. 
Sunarti, E., Tati, Atat, S. N., Noorhaisma, R., \& Lembayung, D. P. (2005). Influence of family economic stress, social support, quality of marriage, parenting, and emotional intelligence of children towards learning achievement of children. Media of Nutrition \& Family, 29(1), 34-40. Retrieved from http://repository.ipb.ac.id/ bitstream/handle/ 123456789/53230/Pengaruh\%20tekanan\%20ekonomi\%20keluarga_\%20Euis $\% 20$ Sunarti-juli05_done.pdf;jsessionid= A0EF259AED95017CFDC4DFF521E0ED7A? sequence $=1$.

Tati. (2004). The influence of family economic stress, social support, and quality of marriage on parenting. (Master's thesis). Retrieved from http://repository.ipb.ac.id/bitstream/handle/123456789/8955/2004tat.pdf?sequ ence $=4 \&$ is Allowed $=y$.

Yigibalom, L. (2013). The role of the interaction of family members in order to maintain the harmony of family life in Kumuluk Village, Tiom District, Lanny Jaya Sub-District. Communications Journal i, 2(4). Retrieved from http://ejournal.unsrat.ac.id/index.php/actadiurna/article/view/2974/2520.

Zastrow, C., \& Ashman, K. K. (1987). Understanding human behavior and the social environment. Chicago, IL: Nelson-Hall, Inc. 